Article

\title{
From Reception to Invention: The Arrival of Concrete to Iceland and the Rhetoric of Guðmundur Hannesson
}

\author{
Sofia Nannini (D) \\ Department of Architecture and Design, Politecnico di Torino, 10125 Turin, Italy; sofia.nannini@polito.it
}

Received: 8 September 2018; Accepted: 18 October 2018; Published: 22 October 2018

\begin{abstract}
The quick modernisation of Iceland, which took place rapidly from the first decades of the 20th century onwards, brought not only fishing trawlers and cars into the country. Among all the techniques of modernity, steinsteypa [concrete] was to become the key material that changed the built landscape of the island and was soon adopted by the first Icelandic architects, such as Rögnvaldur Ólafsson (1874-1914) and Guðjón Samúelsson (1887-1950). Interestingly, the main supporter of this material was Guðmundur Hannesson (1866-1946), a medical doctor and town planning enthusiast who wrote several articles and even a guidebook published in 1921, Steinsteypa. Leiðarvísir fyrir alpýdu og viðvaninga [Concrete: A Guidebook for Common People and Beginners]. In a country that was seeking an architectural self-representation, he understood the technical and formal possibilities that concrete could offer. By analysing his articles and publications, this essay aims to discuss the rhetoric of Guðmundur Hannesson and his role in writing an Icelandic chapter of the history of concrete, from its early stage of unmodern trial-and-error to the definition of a modern Icelandic architecture.
\end{abstract}

Keywords: concrete; construction history; Iceland; Reykjavík; Guðmundur Hannesson

\section{Introduction}

It is commonly known that the history of concrete, since the first trials in the mid-19th century, has been a history originally shaped by a vast and eclectic group of technicians and non-technicians, building experts and amateurs, who all contributed to the rapid growth of this technique (Gabetti 1955; Collins 1959; Forty 2012). The first fathers of concrete, years before the rise of Matthias Koenen's scientific calculation method [Das System Monier, published in 1887] and François Hennebique's first patent (1892), were a blend of gardeners, doctors, entrepreneurs and engineers, from Joseph Lambot (1814-1887) to Thaddeus Hyatt (1816-1901), and from Joseph Monier (1823-1906) to William B. Wilkinson (1819-1902). Despite the distinctive modernity related to concrete and the architectures that it generated, its history of trial-and-error was also "wholly non-modern" (Forty 2012, p. 16) and shows one of the first dichotomies that define this material. Nevertheless, the original un-modernity of concrete can be placed at the roots of the emergence of what historiography today calls, despite some arguments (McLeod 2017), modern architecture. The fascinating role that concrete played at the turn of the century, swinging from its unskilled applications to the birth of an architectural modernity, can be comprehensively described in the small case study of the history of Icelandic construction. Iceland's centuries-long physical and political isolation, together with its harsh climate, is reflected in a lack of an ordinary history of architecture. The first decades of the 20th century were a slow and non-violent struggle for autonomy and independence from Denmark, together with abrupt processes of modernisation and urbanisation of society, and introduced an essential debate into the country on how and what to build in order to represent itself. The difficulty in obtaining timber, the perils of fire and the need to overcome the Danish architectural influence related to the use of stone all indicated 
that a new material should be used in order to give an architectural face to the nation, and that material was concrete. These topics have been discussed in great detail by today's only international academic work on the history of Icelandic architecture (Seelow 2011) and by a dense literature of local architects, engineer, artists and enthusiasts of Icelandic architectural history (Stefánsson 1987; Björnsson 1990; Ágústsson 1998). Among the names of architects and designers who emerged from this peripheral history, such as the State Architect Guðjón Samúelsson (1887-1950), a key role was played by the medical doctor Guðmundur Hannesson (1866-1946), who became one of the strongest advocates of concrete by means of technical arguments and rhetorical narrations. This essay thus aims to highlight the influence that Guðmundur Hannesson had on the Icelandic history of architecture and construction by analysing his writings and placing his work in the wider narrative on concrete as the material of modernity. Moreover, it intends to highlight the role that concrete had within the Icelandic quest for an architectural national style in the first decades of the 20th century.

\section{Guðmundur Hannesson (1866-1946): The Hygiene of Concrete}

Traces of Iceland's fascination with cement, and consequently with concrete, can be found in local newspapers since 1851 (Bóndi 1851; Pétursson et al. 1851), although the first application of cement appears to be even older, in the form of cement-lime mortar on the walls of the Dómkirkjan [Cathedral] of Reykjavík, built in 1847 (Hannesson 1942, p. 241). Yet, it is around the 1870s-80s that the issue of beton, shortly afterwards given the Icelandic name steinsteypa [literally: cast stone], appears to be more and more popular among the newspapers of the island (Helga 1883; Georg 1885). As a matter of fact, in those very years, the first applications of concrete were made by Icelandic builders in the countryside (in Garðar, near Akranes, around 1878-1881, and at a farm of Sveinatunga, in the valley of Norðurárdalur, in 1895). Yet, what can be defined as a truly Icelandic epic of concrete started only at the turn of the century, when Jón Porláksson (1877-1935), one of Iceland's first engineers and a relevant politician, first defined the age that was about to come:

Баð er nú ekki lengur neinum efa undirorpið, að húsagerðarlagið í landinu er að breytast. Timburhúsaöld sú, sem hér hefir gengið yfir um hrið, er að enda, en steinsteypuöldin upp runnin. [There is no longer any doubt that the way we build houses is changing. The age of timber, which has been going on for a while, is about to end, but the age of concrete is rising.] (Porláksson 1911, p. 207)

In this pivotal article (Figure 1), Jón Porláksson addressed for the first time the issue of building with concrete in the countryside, by working together with Búnaðarfélag Íslands [Iceland's Agricultural Society]. In order to "broaden the knowledge of the public on this practice," some questions were printed and sent out to those who had already built farms and houses out of concrete. Interestingly, such inquiry was done “at the country doctor Guðmundur Hannesson's behest” (Porláksson 1911, p. 208).

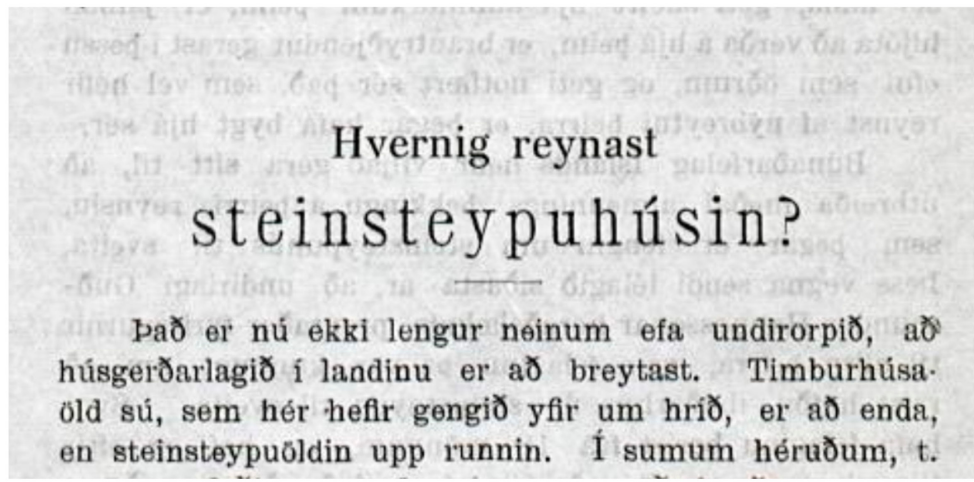

Figure 1. Jón Porláksson, Hvernig reynast steinsteypuhúsin? Búnaðarrit, Vol. 25, 1911. Full article publicly available at tímarit.is. 
Despite the essential role played by the first Icelandic engineers, namely the already mentioned Jón Porláksson and Knud Zimsen (1875-1953), who physically contributed to the spread of concrete construction thanks to their own firms-Mjölnir, founded by Knud Zimsen in 1903 and Steinar, founded by Jón Porláksson in 1905 (Seelow 2011, p. 74)—the real narrator of concrete building, in Reykjavík and in the countryside, was Guðmundur Hannesson. A medical doctor specialising in hygiene in Copenhagen between 1887 and 1894, Guðmundur Hannesson returned to Iceland first as a country doctor in Skagafjörður (1894-1896) and then in Akureyri (1896-1907). He finally settled in Reykjavík from 1907 onwards, as a teacher of medicine and co-founder of the University of Iceland in 1911 (a short biographical note on Guðmundur Hannesson can be found in (Seelow 2011, p. 423); a more detailed biography in (Pétursson and Magnúsdóttir 2016)).

The harsh housing conditions of the Icelandic farmers in the countryside, who still mostly lived in shabby turf houses, became one of Guðmundur Hannesson's obsessions, as he dreamt of offering his fellow countrymen more suitable and hygienic living standards. Consciously or not, he inserted himself into that "important line of propaganda which was to constitute the most effective argument of the partisans of concrete construction" (Collins 1959, p. 43). As suggested by Pétur H. Ármannsson, Guðmundur Hannesson might have visited the social housing project of Brumleby in Copenhagen, designed by Michael Gottlieb Bindesbøll and built by the Danish Medical Association between 1854 and 1872 (Ármannsson 2016). With such an ideal of communal housing in mind, Guðmundur Hannesson very soon started experimenting with drawing and building by himself. Already in September 1902, the newspaper Stefnir, printed in Akureyri, mentioned the doctor's tests: building a house for his family and a small hospital in the town (Stefnir 1902). Yet, his first attempts at building with concrete date back to only 1910, when he was already in Reykjavík. There, he designed and built his own house at Hverfisgata 12 (Figure 2), one of Reykjavík's most central streets and right in front of the newly built Safnahúsið [National Library], the last project designed by a Danish architect and the first public building where structural concrete was used (Seelow 2011, p. 57).

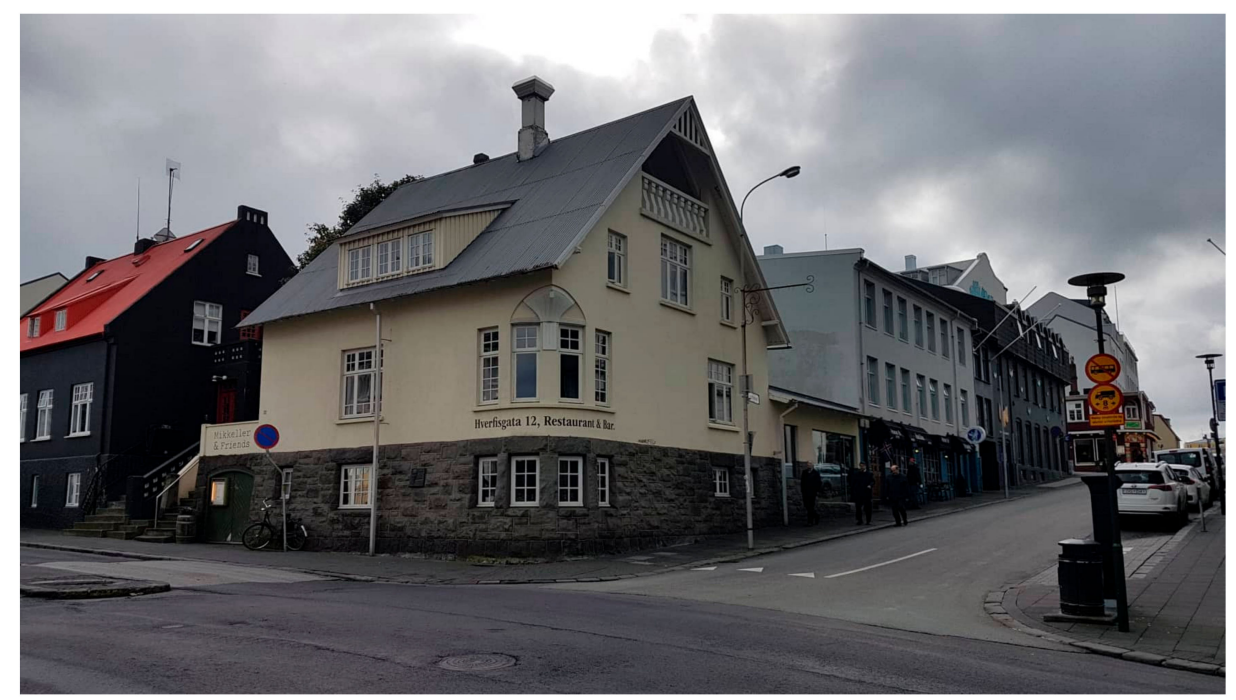

Figure 2. Guðmundur Hannesson's house at Hverfisgata 12, Reykjavík (Photo by Arlène Lucianaz, 2018. Imaged used with permission of the photographer).

Guðmundur Hannesson's house, which still stands today, shows a stone basement [made of Icelandic grágrýti, or dolerite] and cast double walls filled with a padding of sagtródi [sawdust], wood panelling and cardboard. It is especially the insulation layer that defines Guðmundur Hannesson's design signature, as it became the doctor's leading battle in order to teach how to build "Hly og rakalaus steinhús [warm and dry stone houses]." This was the title of an article (Figure 3) published two years after Jón Porláksson's mentioned inquiry among the farmers. In those pages, Guðmundur Hannesson acknowledged, on the one hand, the necessity of building with concrete in "seismic zones"; on the 
other hand, he recognised several "faults" in that kind of construction, that needed improving in order to offer better living conditions and, no less important, a nicer appearance (Hannesson 1913, p. 1).

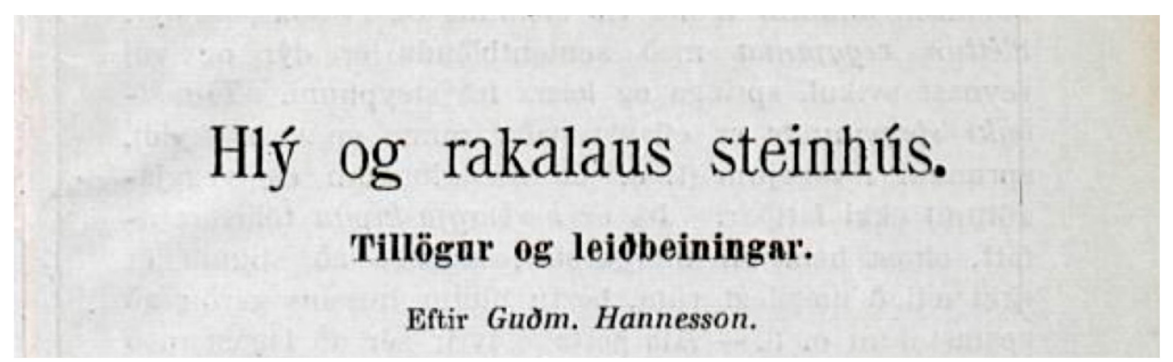

Figure 3. Guðmundur Hannesson, Hlý og rakalaus steinhús, Búnaðarrit, Vol. 27, 1913. Full article publicly available at tímarit.is.

Needless to say, Iceland's greatest threat to everyday living was its extreme climate, which seemed at first not well suited to concrete construction. An interesting account of how badly the first concrete houses were adapted to the lives of the farmers can be traced in the pages of Sjálfstætt Fólk [Independent People], the masterpiece by the Nobel laureate Halldór Kiljan Laxness (1902-1998):

Bjartur was now spending his second winter in the house he had built. It was the worst house in the world and unbelievably cold. [ ... ] The walls of the room sweated with damp and were covered with a veneer of ice during frosty weather. The windows never thawed, the wind blew straight through the house, upstairs there was snow lying on the floors and swirling about in the air. (Laxness 1946, p. 448)

Damp and cold interiors were far too common, especially due to the lack of skilled labour and to the rain while casting the walls, which resulted in houses that were "unsuitable to live in." Moreover, Guðmundur Hannesson asserted that single walls without padding were "far too cold" for construction in the countryside (Hannesson 1913, pp. 3-4). In order to find a solution, the doctor described several methods for casting double walls, showing various sorts of insulating layers. Padding could be of timber and cardboard panels, sawdust, peat chunks, dry turf, or pumice. By use of elementary drawings (Figure 4), the author also suggested different ways of connecting the outer and the inner walls in order to provide more resistance to earthquakes (Hannesson 1913, pp. 14-15).

In the end, the doctor also highlighted the importance of skilled labour while dealing with concrete, which required asking for help from experts, such as the architect Rögnvald Ólafsson (1874-1917), perhaps the leading professional figure in the field at the time (Björnsson 2016). Although the history of concrete construction is usually related to the extensive use of unskilled labour, Guðmundur Hannesson soon understood that in the harsh climate conditions of Iceland the knowledge of building experts was pivotal. By so doing, he also suggested a series of architectural guidelines that would be summed up in his Skipulag sveitabxja [About Farmhouses], published in 1919 (Hannesson 1919). This book proposed new typologies for farmhouses to be built out of concrete, with the aim of modernising the life in the countryside, and opposed the romantic suggestions of the Danish architect Alfred Råvad (1848-1933), who instead strived for a revival of traditional turfhouses (on this debate, see (Seelow 2011, pp. 102-5)). Skipulag sveitabæja reflects Guðmundur Hannesson's major work, Um skipulag bæja [On Town Planning], published in 1916. As a matter of fact, he also distinguished himself as an Icelandic pioneer of urban planning, striving for healthier living conditions in the booming urbanisation of the island. To celebrate its 100-year anniversary, this work has been recently republished with commentary by several Icelandic scholars (Hannesson 1916; Theodórsdóttir and Svavarsson 2016). 


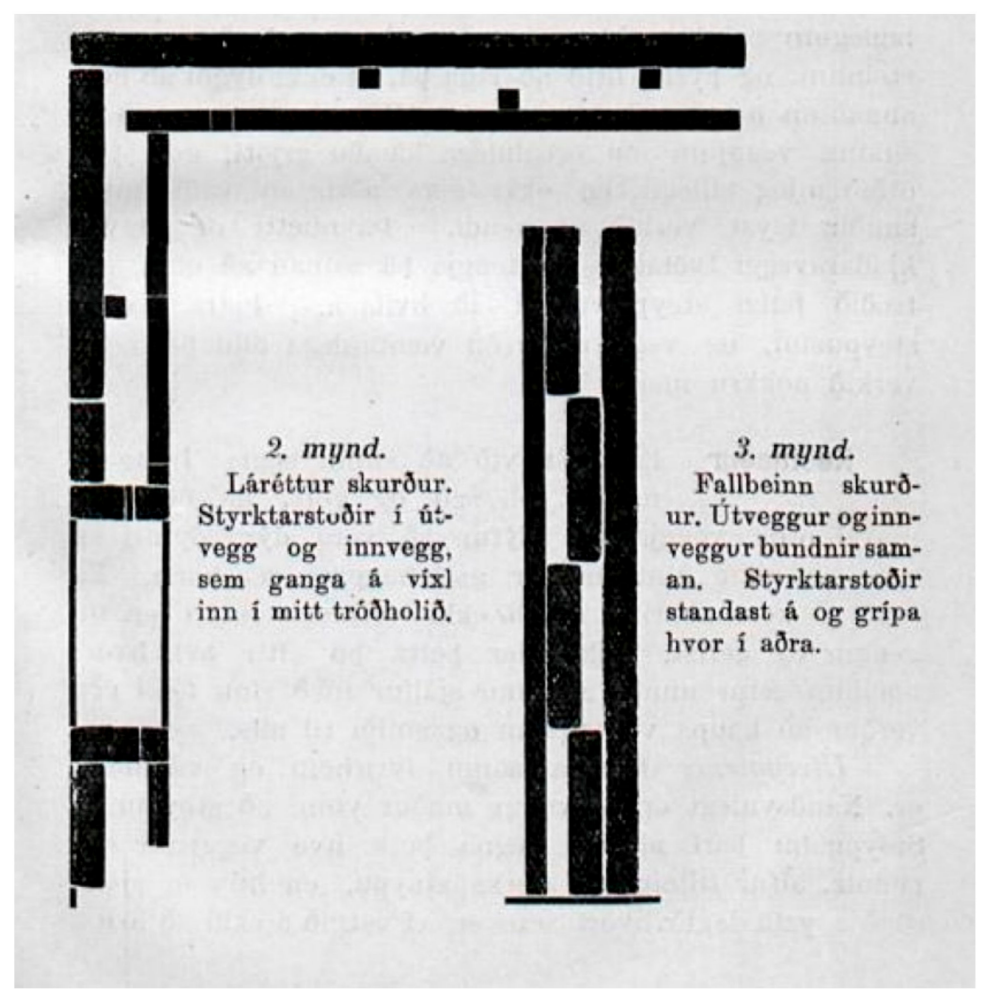

Figure 4. Guðmundur Hannesson, Hlý og rakalaus steinhús, Búnaðarrit, Vol. 27, 1913. Sections of outer and inner walls showing different connections. Full article publicly available at tímarit.is.

Guðmundur Hannesson's article, which dreamt of "warm and dry" houses, was accepted with enthusiasm by those who read Вúnaðarrit, to the point that a few years later a reader wrote about his experience in building a house by following the doctor's suggestions (Guðmundsson 1916). Apparently, such was Guðmundur Hannesson's lifetime dedication, as reported by the doctor's daughter years after his death (Guðmundsdóttir 1974, p. 107), that he was said to have asked his American colleague Alan Gregg - an officer at the Rockefeller Foundation - to put the following inscription as an epitaph on his grave, which still stands today in Reykjavík's cemetery of Hólavallagarður (Figure 5):

GUĐMUNDUR HANNESSON. Hann kenndi Íslendingum að byggja hlý hús.

[Guðmundur Hannesson. He taught the Icelanders how to build warm houses].

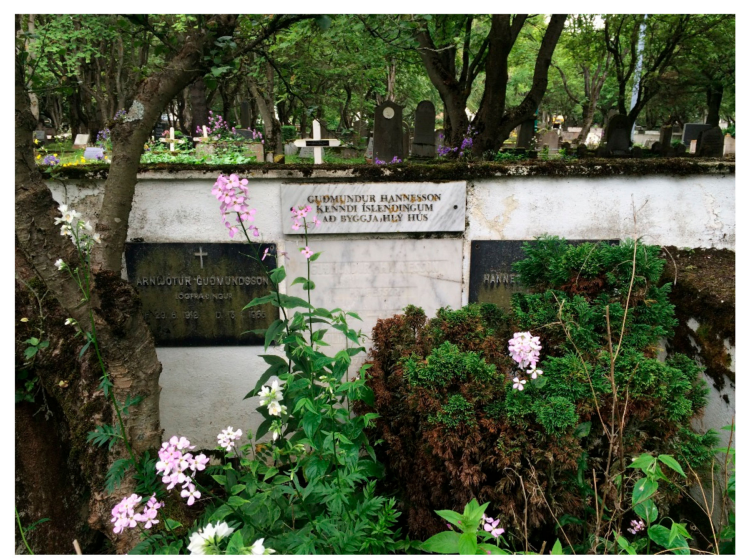

Figure 5. Guðmundur Hannesson's grave and epitaph at Hólavallagarður cemetery, Reykjavík (Photo by the author, 2018). 


\section{Steinsteypa: An Icelandic Guidebook to the Use of Concrete}

Guðmundur Hannesson's technical knowledge and training vocation on the use of concrete reached its peak with the publication of a handbook (Figure 6) titled Steinsteypa. Leiðarvisir fyrir alpýdu og viðvaninga [Concrete: A Guidebook for Common People and Beginners], published in 1921 for Ið̋nfræðafélag Íslands [The Icelandic Craft Society].

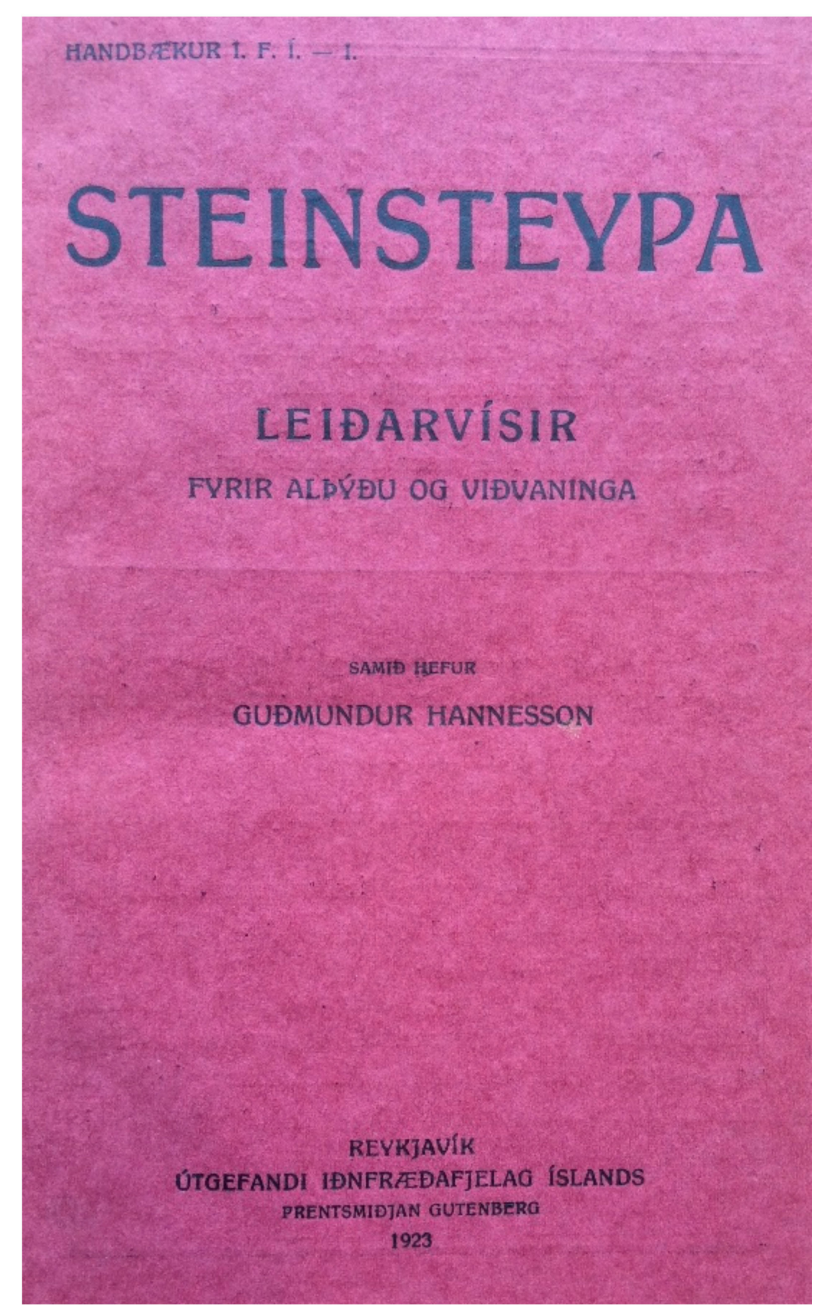

Figure 6. Guðmundur Hannesson, Steinsteypa: Leiðarvísir fyrir alpýðu og viðvaninga, 1921. Book cover. Copy available at the Reykjavík City Library.

In a little more than 100 pages, he offered a record of the composition of the material, its mechanical strength and a brief description of the several applications that concrete might have in the building field. Short notes on the use of iron and steel bars for the reinforcement of concrete were also included (Figure 7), together with axonometrical drawings of wooden formworks (Figure 8) (Hannesson 1921, p. 72). Detailed descriptions of several kinds of timber formworks are included and some of them, in Guðmundur Hannesson's later book titled Húsagerð á Íslandi [The Construction of Buildings in Iceland], will appear with specific names, such as: Sveinatungumót [formwork of Sveinatunga], tangarmót [pliers formwork] and Reykjavikurmót [formwork of Reykjavík] (Figure 9). 


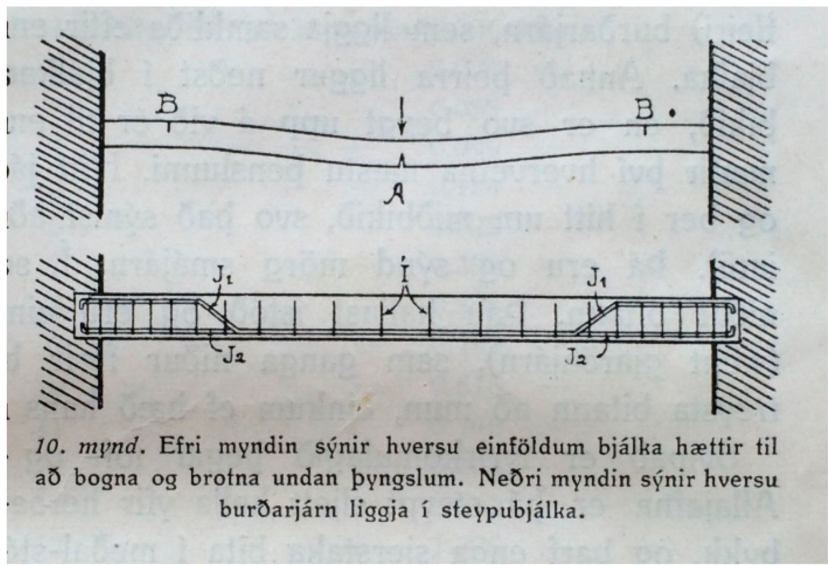

Figure 7. Guðmundur Hannesson, Steinsteypa: Leiðarvísir fyrir alpýðu og viðvaninga, 1921. Explanation of the position of iron bars. Copy available at the Reykjavík City Library.

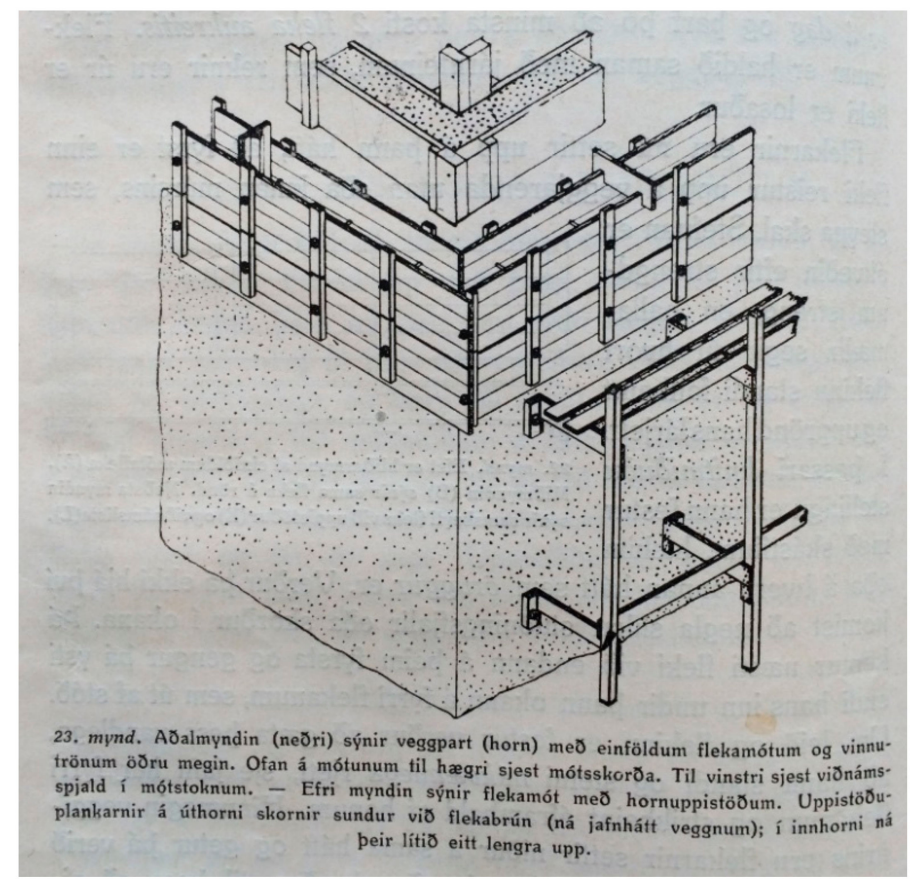

Figure 8. Guðmundur Hannesson, Steinsteypa: Leiðarvísir fyrir alpýðu og viðvaninga, 1921. Details of the formworks. Copy available at the Reykjavík City Library.

While such a guidebook is a unique work among the Icelandic technical literature, it is certainly related to the lively publishing world of reinforced concrete in the first decades of the 20th century. Yet, Guðmundur Hannesson's Steinsteypa is mainly dedicated to unexperienced builders and for the purpose of small constructions. As he stated in the foreword, "[ . . ] enginn viðvaningur skyldi leggja út $i$ að steypa hús, brýr eða annað stórt smíði nema með aðstoð avans manns [A beginner should not venture into casting a house, a bridge or any construction without the help of an expert]" (Hannesson 1921, p. 3). As a matter of fact, its modest scope makes this publication more similar to the Portland Cement Association's 1916 Farmer's Handbook on Concrete Construction, rather than to the highly specialised Handbook on Reinforced Concrete for Architects, Engineers and Contractors published by F. D. Warren in 1906. Yet, there is no trace of such handbooks in the Icelandic library catalogue. As stated by Seelow, "Trotz der offensichtlichen Tatsache, daß Island eine Insel ist, werden die Auswirkungen der geographischen Isolation oft unterschätzt [Despite the obvious fact, that Iceland is an island, the effects of such geographical isolation are often underestimated]" (Seelow 2011, p. 15). This geographical condition might have acted as an isolating factor, but it may prove useful for us to understand 
what kind of technical literature circulated, in those decades, among the readers of such a narrow academic environment. If there is no trace of the French and Belgian publications regarding concrete, despite some mentions of the "Hennebique method" in some newspapers at the turn of the century (Áveitan yfir Skeiðin 1908), the country's library catalogue still bears traces of the rich American and especially German editorial offerings. Frank B. Gilbreth's Concrete System of 1906, the 1905 edition of Der Portland-Cement und seine Anwendungen im Bauwesen and copies of the journal Beton und Eisen: Internationales Organ für Betonbau may be found in the Landsbókasafn [National Library]. Reflecting the country's halfway position in the middle of the Atlantic Ocean, such works culturally and technically place Iceland between the two continents, almost anticipating what would be its future of transatlantic relations after the Second World War.

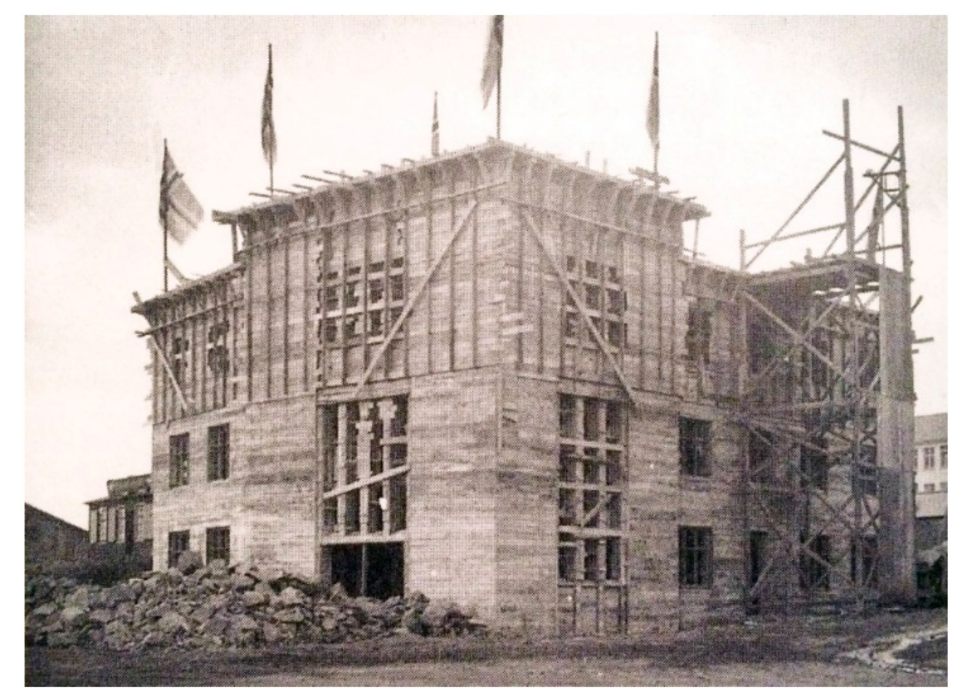

Figure 9. Reykjavikurmót [Formwork of Reykjavik]. Reprinted from: Hörður Ágústsson, Íslensk byggingararfleifð I. Ágrip af húsagerðarsögu 1750-1940, Reykjavík: Húsafriðunarnefn ríkisins, p. 326. The original picture is by Magnus Ólafsson (1862-1937).

Guðmundur Hannesson's frequent mentions of the American and German ways of building with concrete support this view, although a whole different discussion has to be dedicated to the geographies of cement imports. If the author referred to the quality of both "Danish and German cement" (Hannesson 1921, p. 5), the last page of the guidebook shows the advertisement for cement from "Norway's biggest cement factory A/S Christiania Portland Cementfabrik" (Figure 10).

The geographical interdependences related to cement import to Iceland, from Knud Zimsens's " $d e$ facto" monopoly on the trade of cement from Aalborg (Seelow 2011, p. 74) to the Postwar construction of "Sementsverksmiðjan, móðir framtiðarbygginganna á Íslandi [The Cement Factory, the mother of the buildings of the future in Iceland]" (Timinn 1953) still need to be accurately historically researched and are intertwined with the decades-long debate on whether and how to build a cement factory on the island (Guðmundsson 2008).

As for its readers, it is obvious that Guðmundur Hannesson's Steinsteypa was not addressed to an educated public of technicians and engineers, although Iceland seemed to be quite precocious regarding the use of concrete compared to other Nordic countries, with the exception of Denmark. In fact, already in 1906 Denmark boasted several references in one of Germany's most important journals for reinforced concrete, Beton und Eisen (Suenson 1906), and in 1910 the same journal stated that reinforced concrete entered the Danish building industry in 1891 (Mogensen 1910). In particular, the work of the Danish firm Christiani \& Nielsen was well known at the time and its engineers had also designed the bridge over the river Fnjóská in Northern Iceland (Hess 1909). Nevertheless, courses on reinforced concrete and civil engineering were first introduced at the School of Architecture of Copenhagen only in the very years of Guðmundur Hannesson's Steinsteypa (Seelow 2011, p. 78). 


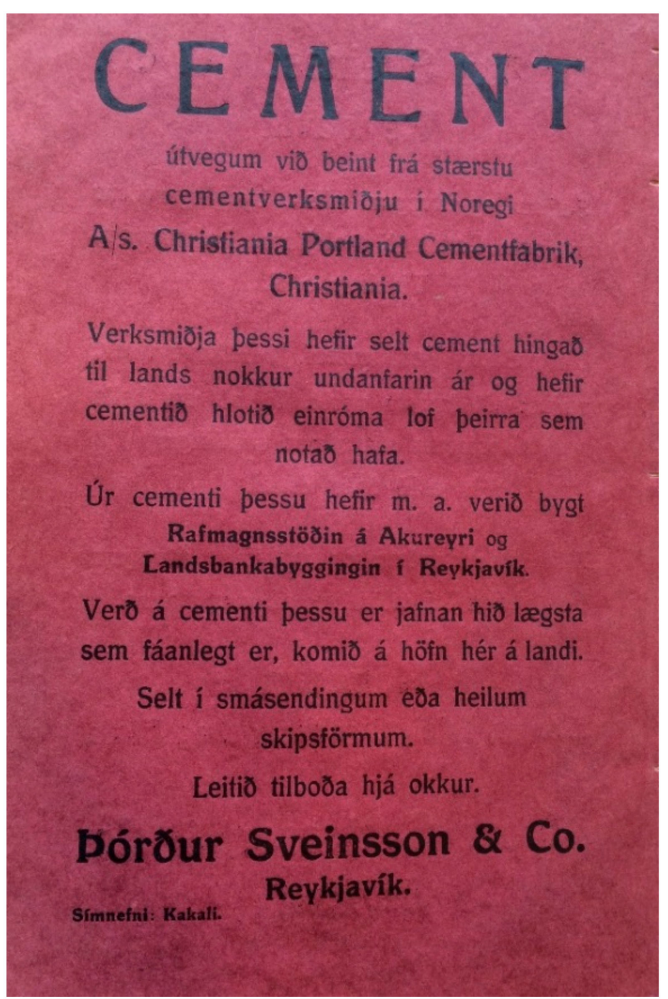

Figure 10. Advertisement for the cement produced at the factory of A/S Christiania, Norway. Copy available at the Reykjavík City Library.

Far from being a guide for numerically calculating structures, the aim of a handbook like Steinsteypa was in agreement with Guðmundur Hannesson's first articles on the application of concrete for building purposes and with his work on the Planning of Farmhouses: that is, to help Icelanders during the transition from turf to the materials of modernity. When the first building code for Reykjavík was approved in 1903-quite ahead of the times compared to other countries-it was stated that "Torfbæi og torfhús má ekki byggja [Houses and farms of turf cannot be built]" (Byggingarsampykkt fyrir Reykjavik 1903). Moreover, suggestions regarding the mix ratio of concrete were already given. Therefore, a work like the Steinsteypa handbook was indeed part of a wider attempt to help builders follow more carefully the new building regulations that the country was adopting.

\section{4. “To Build out of a New Material with a New Form": The Quest for a Modern Style}

The cold climate and the technical obstacles were not the only issues that Guðmundur Hannesson had to face while dealing with the new material. He also had to deal with the social and political issue of style:

Íslendingar lifa nú á hættulegu gelgjuskeiði i öllu sem að byggingum lýtur og petta hefir aftur mikil áhrif á alt pjóðlif vort. Í púsund ár höfðum vér ekki úr öðrum byggingaefnum að spila en baggatækum spýtum, torfi og óhöggnu grjóti.

[The Icelanders are now living in a dangerous state of puberty when it comes to buildings and this has a great influence on our national life. For 1000 years we have not played with other building materials than pieces of wood, turf and uncut stone]. (Hannesson 1926, p. 13)

Abandoning the centuries-long tradition of grass-covered roof and turf farms, "the sort of farmhouse that is built by instinct," as Laxness wrote (Laxness 1946, p. 453), Hannesson met with resistance to this new kind of construction, both in the countryside and in the growing city of Reykjavík. Laxness, once again, sharply described the rejection some farmers expressed of these new buildings: 
In the evening Asta took her children down to the brook and stood staring in wonder at this ugly house with the sharp corners, the impressions left on the concrete by the boards in the moulds, the dabs of cement on some of the windows, the broken panes of others, and the holes that had been dug in the earth all around. New though it was, it reminded one of the ruins of a building shelled in the war. Such was the palace he had built in the dream that she would return. She, too, had once upon a time dreamed of a bright house in a green meadow by the sea. (Laxness 1946, p. 468)

In an article published in 1926 and titled "Húsakynni á Norðurlöndum: Að fornu og nýju" [Housing in the Nordic Countries: Now and Then], Guðmundur Hannesson described the characteristics of country housing in Sweden and Norway, yet asserting in the end that "útlendar fyrirmyndir henta ekki að öllu, pó að hugmyndir geti pær gefið og nokkra leiðbeiningu [foreign models are not suitable for everything, although they can give some ideas and instructions]" (Hannesson 1926, p. 36). What is remarkable is the author's urgency in terms of defining the "breytinga-og byltingaöldin [age of change and revolution]" that he was experiencing. He asserted that the "new materials" had come and the construction of foreign countries, seen by the travelling Icelanders "with their own eyes," was "much better than ours." Therefore, all these changes led to the need for building "úr nýju efni með nýju sniði [out of a new material with a new form]." Interestingly, Guðmundur Hannesson mentioned the fact that "we had no architects, who had comprehensive knowledge and mature taste regarding these materials and who could guide people. There is a great difference between being a good carpenter and a good architect" (Hannesson 1926, pp. 13-14).

It is not a coincidence that these words were written in the past tense: "we had no architects," Guðmundur Hannesson claimed in 1926, thus implicitly stating that by then the situation had changed. In fact, it had: in 1926 not only had Iceland obtained political autonomy [Fullveldi] from Denmark (on 1 December 1918), but the country already boasted of the figure of a State Architect [Húsameistari rikisins], whose office was literally changing the architecture and the urban structure of Reykjavík. From 1919 to his death in 1950, the role of the State Architect was assigned to Guðjón Samúelsson, an architecture graduate of the Royal Academy of Fine Arts of Copenhagen. His works already included, by 1926, the Verzlunharhús Nathan og Olsens [Nathan \& Olsen's Store], built in 1916-1917 in the city centre of Reykjavík, an unbuilt project for the Parliament of 1917 and the design of Landakotskirkja, the Catholic church dedicated to Christ the King, eventually built in 1929. Although Guðjón Samúelsson's architecture and quest for a national style have already been described (Seelow 2011, pp. 107-55), what is important to highlight is the great influence that concrete had on the State Architect's design. The presence of concrete, chosen both for the structure and for the finishing of all the buildings designed by Guðjón Samúelsson, was so pervasive that Icelandic concrete could very well be listed together with the more famous "national concretes" that emerged after the decline of the patent system (Forty 2012, p. 119).

Furthermore, because of the political meaning associated with the State architecture, concrete assumed new connotations that went beyond the mere debate on the practical and technical issues highlighted by Guðmundur Hannesson. As underlined by Seelow, this material became a metaphorical tool for the "liberation from the Danish building technique and architecture" (Seelow 2011, p. 73). This nationalist affirmation of the country's political status through architecture and its materials was endorsed enthusiastically by the politician Jónas Jónsson, also known as Jónas frá Hriflu, (1885-1968), in an equally enthusiastic and nationalist book (Figure 11) titled Íslenzk Bygging: Brautryðjandastarf Guðjóns Samúelssonar [Icelandic Construction: The Pioneering Work of Guðjón Samúelsson]: "Steinsteypan var fyrsta varanlega byggingarefni Íslendinga [Concrete was the first enduring building material of the Icelanders]" (Jónsson 1957, p. 108). Jónas Jónsson was an extremely influential politician related to the centre-right Framsóknarflokkurinn [Progressive Party], and his endorsement for steinsteypa placed concrete within a very interesting debate, confirming that "Concrete is political in many senses" (Forty 2012, p. 145). As a matter of fact, concrete in Iceland was not only going to be the building material of functionalism that reached the island after 1930 (Seelow 2011, p. 175), but also became a 
physical metaphor for the rhetoric of a truly "Icelandic construction", in the heated quest for a national style that spread through the country in the years before independence.

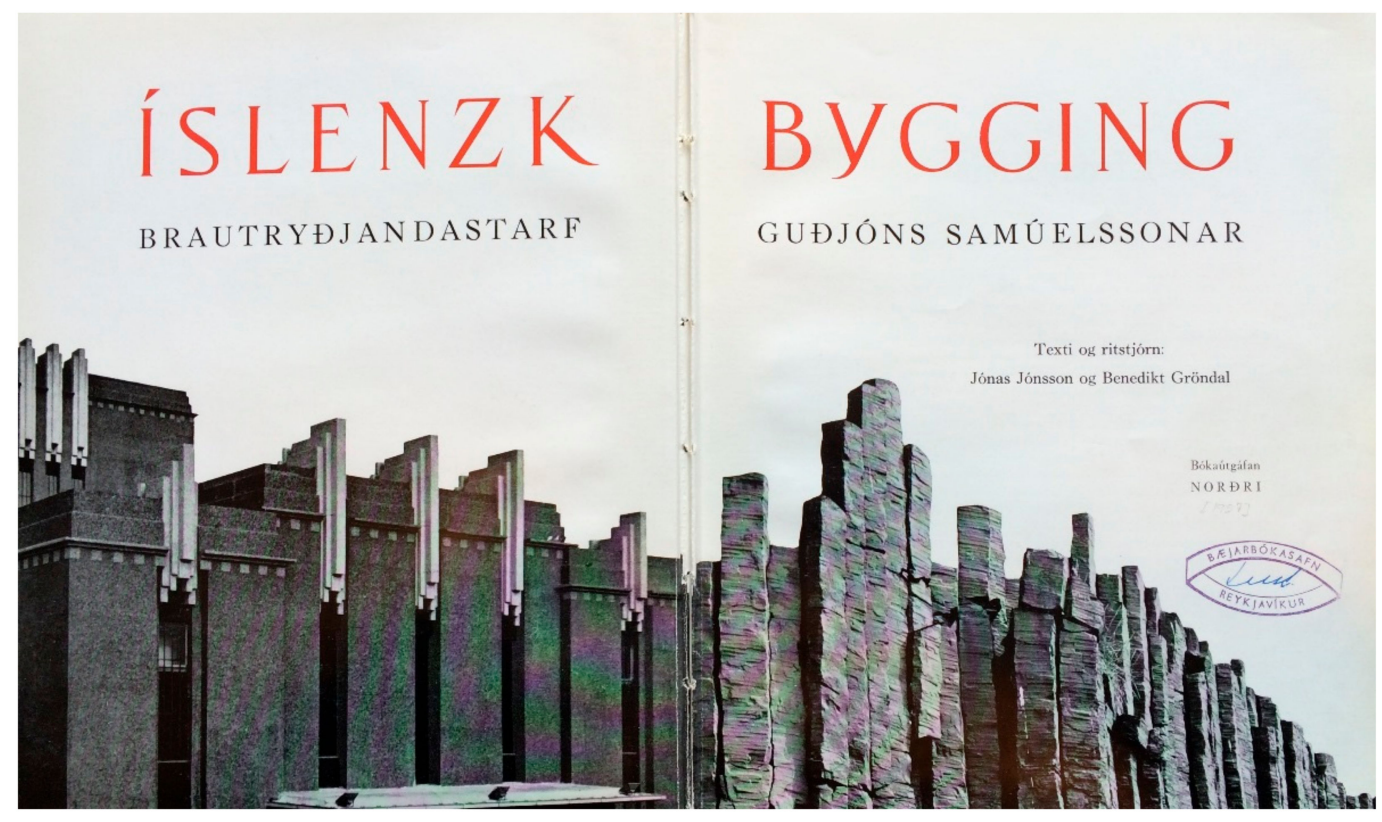

Figure 11. Jónas Jónsson, Íslenzk Bygging: Brautryðjandastarf Guðjóns Samúelssonar, Reykjavík: Norðri, 1957. Copy available at the Reykjavík City Library.

\section{Húsagerð á Íslandi: The Icelandic Invention of Concrete}

The last and greatest contribution that Guðmundur Hannesson made to the history of Icelandic construction was the book Húsagerð a Íslandi [Construction of Buildings in Iceland], published in 1942. This work embraced all aspects of construction history on the island, from its settlement to the author's present times, with special attention to the different materials that had been used throughout history - turf, timber, stone and, lastly, cement and concrete. The major difference between Guðmundur Hannesson's first articles and this last work was their scope: in Húsagerð a Íslandi, the author was not only interested in the use of the building materials—in particular, of concrete—but in their historic connections to Iceland.

"Sagan um steinsteypuna er xfintýri likust [The history of concrete is like a fairytale]": this is how the chapter on Steinsteypuhús [Concrete houses] begins (Hannesson 1942, p. 240). Interestingly, the way in which he traces the history of concrete in the country, from the early tests of local builders to the works of the most important architects of that time, may be seen as an epic narration. Firstly, the author briefly mentions the discovery of Portlandsement by quoting both John Smeaton (1724-1792), an English engineer and one of the pioneers of hydraulic lime (Gargiani 2013, p. 316), and Joseph Aspdin (1778-1885), who first patented the so-called Portland cement. Secondly, he refers to the French pioneer Joseph Monier and his first trials with reinforced concrete. Then, he draws some comparisons with other countries: if "in Denmark cement and concrete were little used before the works at the port of Esbjerg in 1860," "the Germans were quicker at adopting concrete and they built the first cement factory in Stettin in 1855" (Hannesson 1942, p. 241). Apparently, the first kalksteypuhús [house made of cast limestone] was built by Sigurður Hannsson in Garðar, near Akranes, around 1876-1881 and, as Guðmundur Hannesson claimed with pride, "Detta var fyrsta steypuhúsið hér á landi og liklega á Norðurlöndum [This was the first cast stone house in Iceland and possibly in the Nordic countries]" (Hannesson 1942, p. 242). The walls were composed of cast stones, made of a mixture of ground blágrýti [basalt], lime, some cement and sand. A little more than a decade later, in 1895, the same builder, together with the farmer Jóhann Eyjólfsson, constructed the farm of Sveinatunga in the valley of Norðurárdalur, which was defined as the first house properly made 
with cast concrete walls, whose cement-sand-gravel mix ratio was 1:2:2 (Hannesson 1942, p. 246). The results of this construction may be similar to some previous trials with the so-called "Stampfbeton," or "Pisé-beton," already used by the French pioneer François Coignet (1814-1888) since the mid-18th century (Kierdorf and Hilsdorf 2010, p. 23).

After these short explanations, Guðmundur Hannesson gets to his point: the ultimate rhetoric of a national narration on concrete is simply that they - these builders in the Icelandic countryside-invented concrete on their own. Yet, the history of concrete is made up of "vieler kleiner, aufeinanderfolgender oder auch zeitlich paralleler Erfindungen [many, small, consecutive or even temporally parallel inventions]" (Kierdorf and Hilsdorf 2010, p. 11). As Forty claims, "The early development of reinforced concrete in the nineteenth century was not attached to a particular time or place; rather it was invented several times, in slightly different ways and in different places" (Forty 2012, p. 15). Could it be that Iceland was one of these "different places"? Guðmundur Hannesson's curious attempt to write a concrete saga wanted the readers to accept his truth:

Where did this knowledge come from? It did not come from educated men, who could read foreign languages and neither from those, who had travelled and seen foreign examples. (Hannesson 1942, p. 242)

This led the author to claim that: "Hér voru pá íslenzkur sveitabóndi og steinsmiður að gera tilraunir eftir sinu höfði og uppgötvuðu sementssteypu! [There was an Icelandic farmer and a builder, who were making some attempts on their own and they discovered concrete!]" (Hannesson 1942, p. 247). Despite the surreal change of the geographical barycenter that such an acknowledgment would lead to, within the history of concrete, what has specifically been invented by the Icelanders-and by Guðmundur Hannesson in particular-was not of course concrete, but the rhetoric and all the meanings of identity around it, which would shape all the future paths of Icelandic architecture in the decades to come.

Funding: This research received no external funding.

Acknowledgments: The author wishes to thank Guðmundur Guðmundsson for his support and Alberto Bologna and Atli Magnus Seelow for their important help.

Conflicts of Interest: The author declares no conflict of interest.

\section{References}

Guðmundsdóttir, Anna. 1974. Dr. Guðmundur Hannesson prófessor. In Faðir Minn Læknirinn. Hafnarfjörður: Skuggsjá, pp. 83-108.

Theodórsdóttir, Ásdís Hlökk, and Sigurður Svavarsson, eds. 2016. Aldarspegill. Samtal við Guðmund Hannesson. Reykjavík: Hið Íslenska Bókmenntafélag.

Áveitan yfir Skeiðin. 1908. Búnaðarrit, vol. 22, p. 164.

Björnsson, Björn G. 2016. Fyrsti Arkitektinn. Rögnvaldur Ágúst Ólafsson og Verk Hans. Reykjavík: Hið Íslenska Bókmenntafélagið.

Guðmundsson, Björn. 1916. Hlý og rakalaus steinhús. Búnaðarrit, vol. 30, pp. 73-77.

Bóndi. 1851. Tilraunir og uppástungur ýmsra manna um bæjabyggingar. Bóndi, vol. 1, p. 42.

Byggingarsampykkt fyrir Reykjavik. 1903. Stjórnartíðindi fyrir Îsland. Árið 1903. Reykjavík: Prentsmiðju Ísafoldar.

Collins, Peter. 1959. Concrete: The Vision of a New Architecture. A Study of Auguste Perret and his Precursors. London: Faber and Faber.

Forty, Adrian. 2012. Concrete and Culture: A Material History. London: Reaktion Books.

Gabetti, Roberto. 1955. Origini del Calcestruzzo Armato. Torino: Ruata.

Gargiani, Roberto. 2013. Concrete from Archeology to Invention, 1700-1769. Lausanne: EPFL Press.

Georg, Ahrens. 1885. Um sementsteypu. Fjóðólfr, vol. 37, p. 1.

Guðmundsson, Guðmundur. 2008. Sementsiðnaður á Íslandi i 50 ár. Reykjavík: Verkfræðingafélag Íslands.

Hannesson, Guðmundur. 1913. Hlý og rakalaus steinhús. Tillögur og leiðbeiningar. Búnaðarrit, vol. 27, pp. 1-26.

Hannesson, Guðmundur. 1916. Um Skipulag Bæja. Reykjavík: Háskóli Íslands.

Hannesson, Guðmundur. 1919. Skipulag Sveitabæja. Reykjavík: Porsteinn Gíslason. 
Hannesson, Guðmundur. 1921. Steinsteypa. Leiðarvísir Fyrir Alpýðu og Viðvaninga. Reykjavík: Iðnfræðafjelag Íslands.

Hannesson, Guðmundur. 1926. Húsakynni á Norðurlöndum að Fornu og Nýju. Skírnir, vol. 100, pp. 13-37.

Hannesson, Guðmundur. 1942. Húsagerð á Íslandi. Reykjavík: Prentsmiðjan Edda H. F.

Helga, Helgason. 1883. Um steinsteypu. Fróði, vol. 4, p. 113.

Hess, L. 1909. Fnjóská-Brücke auf Island. Beton und Eisen. Internationales Organ für Betonbau, vol. 8, p. 188.

Stefánsson, Hjörleifur. 1987. Kvosin. Byggingarsaga Miðbæjar Reykjavikur. Reykjavík: Torfusamtökin.

Ágústsson, Hörður. 1998. Íslensk Byggingararfleifð I. Ágrip af Húsagerðarsögu 1750-1940. Reykjavík: Húsafriðunarnefn ríkisins.

Porláksson, Jón. 1911. Hvernig reynast steinsteypuhúsin? Búnaðarrit, vol. 25, pp. 207-27.

Jónsson, Jónas. 1957. Íslenzk Bygging. Brautryðjandastarf Guðjóns Samúelssonar. Reykjavík: Norðri.

Kierdorf, Alexander, and Hubert K. Hilsdorf. 2010. Zur Geschichte des Bauens mit Beton. In Was der Architekt vom Stahlbeton Wissen Sollte: Ein Leitfaden Für Denkmalpfleger und Architekt. Edited by Uta Hassler. Zürich: Gta Verlag, pp. 11-51.

Laxness, Halldór Kiljan. 1946. Independent People. New York: Alfred A. Knopf. First published 1934-1935.

Björnsson, Lýður. 1990. Steypa Lögð og Steinsmíð Rís. Sagt Frá Mannvirkjum úr Steini og Steypu. Reykjavík: Hið íslenska bókmenntafélag.

McLeod, Mary. 2017. Modernism. History of Postwar Architecture. [CrossRef]

Mogensen, Emil. 1910. Einige Eisenbetonbauten in Dänemark. Beton und Eisen. Internationales Organ für Betonbau, vol. 15, pp. 361-64.

Pétursson, Páll, and Sigrún Magnúsdóttir. 2016. Athöfn var helguð hver ævinnar stund. In Aldarspegill. Samtal við Guðmund Hannesson. Edited by Ásdís Hlökk Theodórsdóttir and Sigurður Svavarsson. Reykjavík: Hið Íslenska Bókmenntafélag, pp. 82-103.

Ármannsson, Pétur H. 2016. Húsakostur og heilsufræði. In Aldarspegill. Samtal við Guðmund Hannesson. Edited by Ásdís Hlökk Theodórsdóttir and Sigurður Svavarsson. Reykjavík: Hið Íslenska Bókmenntafélag, pp. $28-49$.

Pétursson, Pétur, Jens Sigurðsson, and Gísli Magnússon. 1851. Tíðindi Frá Pjóðfundi Íslendinga. Reykjavík: Prentsmiðjan landsins.

Seelow, Atli Magnus. 2011. Der Moderne Architektur in Island in der Ersten Hälfte Des 20. Jahrhunderts: Transferprozesse Zwischen Adaption und Eigenständigkeit. Nürnberg: Verlag für Moderne Kunst.

Stefnir. 1902. Húsabyggingar á Akureyri. Stefnir, vol. 10, p. 31.

Suenson, E. 1906. Zur Geschichte des Eisenbetons in Dänemark. Beton und Eisen. Internationales Organ für Betonbau, vol. 6, pp. 137-38.

Tíminn. 1953. Eftir fá ár geta Ísledingar byggt eingögnu úr íslenzku sementi. Tíminn, vol. 37, p. 140. 